\title{
日本獣医師会『会報』
}

論 説

シルバー獣医師による家畜衛生分野の国際協力

緒方宗雄（社)畜産技術協会参与）

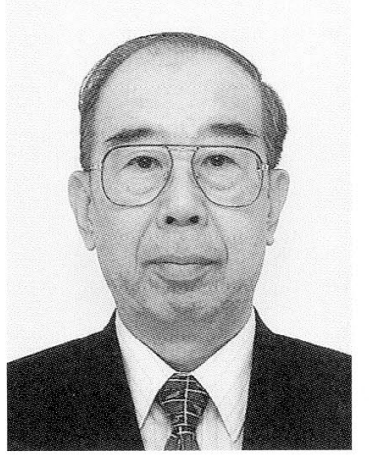

1. わが国のODA

国際化が進展するなか で，開発途上国が自主的， 自立的に発展できるよう支 援することは，先進国にと って共通の責務とされてい る。とりわけ政府開発援助 (Offical Development Assistance, ODA）は，わが 国が国際社会の安定と繁栄の実垷に向けて取り組むため の重要な手段と位置付けられ，開発途上国の経济開発や 福祉の向上に役立つことを拈もな目標としている。わが 国は，ODA を通じて国際社会の平和と安定に重要な役 割を果たすことにより，国際平和に依拠し，資源・食料 を海外に依存する日本にとって，国民生活を守り，自国 にとって好ましい国際環境を構築するなど，国益の増進 に寄与するものとされている。

国は，このようなODA事業のあり方として1992 年に 「政府開発援助大綱」を決定し，その基本理念として， 人道的配慮, 相互依存性の認識, 環境の保全, 自助努力 支援の 4 項目をあげている。

ODA予算にみるかぎり，わが国は1991 年以降，世界 第 1 位の援助国であったが，現在は大きな転換期を迎え ている。すなわち国際事情の変化とわが国の経済事情等 をもとに抜本的な見直しが求められ，平成 14 年度の ODA 予算は，厳しい経済・財政事情等を背景に約 $10 \%$ の削減となっている。日本は世界第 1 位の援助国の地位 を米国に譲っただけでなく，援助の額もさることなが ら，従来にも増して，その質を問われるわけである。

平成 12 年度の ODA 実績は総額で 1 兆 4,562 億円に 達し，国民一人あたり約 1 万円を負担していることにな る。この額が多いか少ないか，観る人によって異なるだ ろうが，ODA 予算は国民の税金であることを考えると き，おろそかにできないことはいうまでもないだろう。

ODAのなかで，途上国の人造り（人材養成と技術向

上）を目的とする技術協力は，いわゆる顔の見える援助

日獣会誌 $55 \quad 461 \sim 463(2002)$
と位置付けられる。この分野の援助事業は国際協力事業 団（JICA）が担当しており，平成 12 年で ODA 支出実 績の $26.5 \%$ (3,857 億円) を占めているが，そのおもな る内訳は（1）途上国からの研修員の受け入れ，(2) 専 門家の派遣，（3）青年海外協力隊員の派遣，（4）機材の 供与等となっている，本稿では，主として人を通じての 技術協力について述べてみたい。

\section{2. 畜産分野の技術協力は}

家畜衛生を含む音産分野の技術協力の状況はどうであ 万うか。

開発途上国では，特に低所得国において栄養不足に陥 っている人口が8億人以上といわれ，一方では先進国と 開発途上国との食料消費の格差も拡大している，食料の 増産や栄養代足の解消は, 開発途上国の最大の課題のひ とつであり，国民所得や就業人口に大きなウェイトを占 める農林水産部門の自立的な発展は，国の経済・社会の 安定基盤として重要な部門と位置付けられる。

このような背景から，農林水産分野の技術協力はわが 国の技術協力の歴史の中で，古くからから重要な分野と なってきたが，なかでも家畜衛生を中心とする畜産協力 は，先人の努力もあって各地において宸業協力の先駆的 な役割を演じてきた。畜産協力の実績の一部を表 1 に示 した.

各事業ともに，近年になって急速に拡大していること が伺われる。畜産を含めて農業分野の伸びは全体のそれ には及ばないが，畜産分野だけでも，年間に 300 名を上 回る研修員を受け入れ，200名にも達する専門家を派遣 し, 100 名内外の青年海外協力隊員を派遣している.

日本のODAが開始されてから 2000 年までの約半世 紀にわたって，畜産分野では研修員の受人は累計で 4,044 名，専門家派遣 1,866 名, 協力隊員派遣 860 名に 達している。

途上国の政府関係技術者を対象とする研修員の多くは 家畜改良センター，家畜衛生試験場（現在の動物衛生研 究所), 都道府県の畜産試験場等, 大学, 民間研究機関 等で受け入れられ，派遣専門家は国および都道府県，大 
表 1 畜産協力のおもなる実績

（1）研修員等の受け入れの推移（人）

\begin{tabular}{|c|c|c|c|}
\hline 年 度 & 全 体 & うち農水分野 & うち畜産分野 \\
\hline 昭和 50 年度 & 2,155 & $475(22.0 \%)$ & $31(6.5 \%)$ \\
\hline 55 年度 & 3,393 & $569(16.8 \%)$ & $47(8.3 \%)$ \\
\hline 60 年度 & 5,549 & $895(16.1 \%)$ & $111(12.4 \%)$ \\
\hline 平成 2 年度 & 7,556 & $1,191 \quad(15.8 \%)$ & $142(11.9 \%)$ \\
\hline 7 年度 & 10,458 & $1,666(15.9 \%)$ & $209(12.5 \%)$ \\
\hline 12年度 & 17,513 & $2,277(13.0 \%)$ & $350(15.3 \%)$ \\
\hline
\end{tabular}

出所：JICA年報より，員数は各年度の新規受入分のみ. \%は，それぞれ前欄に対する比率，以下，同じ.

（2）専門家派遣（短期 - 長期）の推移（人）

\begin{tabular}{rcrrr}
\hline \hline 年 度 & 全 体 & うち農水分野 & うち畜産分野 \\
\hline 昭和50年度 & 1,082 & $372(34.4 \%)$ & $26(7.0 \%)$ \\
55 年度 & 2,415 & $737(30.5 \%)$ & $46(6.2 \%)$ \\
60 年度 & 2,838 & $811(28.6 \%)$ & $98(12.1 \%)$ \\
平成 2 年度 & 3,970 & $1,190(30.0 \%)$ & $135(11.3 \%)$ \\
7 年度 & 4,910 & $1,508(30.7 \%)$ & $172(11.4 \%)$ \\
12 年度 & 5,218 & $1,299(24.9 \%)$ & $191(14.7 \%)$ \\
& {$[3,381]$} & {$[695]$} & {$[114]$} \\
\hline
\end{tabular}

出所：JICA年報より, 人員数は各年度の新規と継続派遣 の合計, [ ] 内は, 平成 12 年度の新規派遣員数

（3）青年海外協力隊の隊員派遣の推移（人）

\begin{tabular}{rrrr}
\hline \hline 年 度 & 全 体 & うち農水分野 & うち畜産分野 \\
\hline 昭和50年度 & 677 & $240(35.5 \%)$ & $39(16.3 \%)$ \\
55 年度 & 1,137 & $340(29.9 \%)$ & $54(15.9 \%)$ \\
60 年度 & 2,204 & $491(22.3 \%)$ & $105(21.4 \%)$ \\
平成 2 年度 & 2,681 & $555(20.7 \%)$ & $137(24.7 \%)$ \\
7 年度 & 3,412 & $597(17.5 \%)$ & $116(19.4 \%)$ \\
12 年度 & 3,877 & $698(18.0 \%)$ & $96(13.8 \%)$ \\
& {$[1,370]$} & {$[220]$} & {$[31]$} \\
\hline
\end{tabular}

出所：同上, 員数は各年度の新規と継続派遣の合計, [ ] 内は，平成 12 年度の新規派遣員数

学関係，民間研究機関，家畜共済等の現役の技術者や $\mathrm{OB}$ ，さらには協力隊 $\mathrm{OB}$ といった多様な職域から派遣さ れている．このような幅広い人的交流が，専門分野のみ ならず，日本と途上国の相互理解や国際親善にも大きく 貢献していることはいうまでもないだろう。

技術協力事業のひとつに「プロジェクト方式技術協 力」というのがある．相手国の開発計画などに応じ，技 術の移転と普及を図ることを目的に，研修員の受入，専 門家の派遣，機材の供与の三つの協力形態をひとつの事 業計画（プロジェクト）として統合して実施するもの で，計画的で総合的な大型の技術協力の形態といえるだ ろう。畜産分野のプロジェクト協力のすべてを紹介して いる余裕はないが，過去 30 年間の畜産プロジェクトは 合計で 38 件，その実施地域は東南アジアを中心に中南 米地域, 中近東，アフリカ，東欧地域にまで及んでい る. 現在, 進行中の畜産関連プロジェクトはアフターケ
ア事業を含めて 16 件に達し，うち家畜衛生分野に属す るものは夕イ，ヴェトナム，モンゴル，アルゼンチン， メキシコでそれぞれ展開中である（繁殖関係，人工授精 等は畜産にカウントした).

\section{3. 畜産協力の広がり}

現在，わが国の ODAは貧困対策，社会開発，人材育 成，食料・農村開発を四大重点事項としてかかげ，協力 地域としては引き続きアジア地域に重点を置くと同時 に，世界全体の貧困や経済の困難に目を向けるとしてい る.

多くの国々で，畜産は農業のなかでいぜん大きな役割 を有しており，国民の大半が農業に従事する開発途上国 の農村と農業の振興の上で畜産の重要性は高い. 加えて 途上国の経済発展と所得の向上は，必然的に動物性食品 の需要の増加をもたらし，畜産開発協力は従来にもまし て必要度が高くなってきつつあると認識される。

過去の協力事業の動向を振り返ってみよう. 畜産協力 はおもに家畜伝染病の予防や防圧から始まった。ワクチ ン製造や疾病診断等の家畜伝染病対策は公共性，公益性 が高く，畜産振興の基盤であると同時に家畜畜産物の輸 出入に関連して国際性が高く，地域の疾病事情は異なる としても，共通の学問的，技術的土台にたつものと認識 されるからであろう。さらに畜産協力は損耗防止を目的 とする家畜衛生対策に加えて, 積極的な生産対策とし て, 繁殖 - 人工授精, 飼養管理技術, 育種改良, 草地 · 飼料生産等の技術分野に拡大した。ついで生産された畜 産物の処理・加工，安全性の確保といった分野にも進展 し，情報化時代を反映して，先端技術やバイオ技術等に ついての要請も増加している．技術者や研究者の養成そ のものも協力課題となってきた。「貧困からの解放」や 「住民参加型協力」の視点から，個別的技術から始まっ て地域開発協力にみるようなトータル・アプローチが注 目されるようになった。

そして，このような協力事業を現地において展開する 有能な専門家の養成と確保が，一段と重要となってき た。

\section{4. シニア海外ボランティア制度の発足}

国際化時代に対応して，各地の大学等でいわゆる文系 の国際関係学科 (学部) 等が輩出しているが，畜産・家 畜衛生を含めて科学技術分野の技術協力に従事する専門 家を制度的に養成する国内の関係機関は見当たらない。 専門家のソースを拡大し，途上国で必要とする専門技術 者を計画的に養成する必要があるものの，それを取り巻 く社会環境条件は厳しく，長年の懸案事項となってい 万.

このような背景のなかで，1991 年度から始まった本 
表-2 シニア海外ボランティアの派遣

（1）シニア海外ボランティア派遣の推移（人）

\begin{tabular}{|c|c|c|c|c|}
\hline 年 度 & $\begin{array}{l}\text { 新規 } \\
\text { 派遣 }\end{array}$ & \multicolumn{2}{|c|}{$\begin{array}{l}\text { 年度末時点 } \\
\text { の派遣数 }\end{array}$} & $\begin{array}{l}\text { 派遣 } \\
\text { 累計 }\end{array}$ \\
\hline 平成 9 年度 & 39 & 11力国 & 67 & 168 \\
\hline 10 年度 & 58 & 12力国 & 79 & 217 \\
\hline 11年度 & 98 & 15力国 & 146 & 325 \\
\hline 12年度 & 186 & 16力国 & 261 & 511 \\
\hline 13年度 & - & 27力国 & 386 & 662 \\
\hline
\end{tabular}

出所：JICA年報より

（2）畜産関連のボランティア派遣の実績（派遣中を含む）

\begin{tabular}{|c|c|c|c|}
\hline 派 遣 国 & 指導科目 & 配 属 先 & 派遣期間 \\
\hline ジョルダン & 産 & $\begin{array}{l}\text { クイーン・アリア } \\
\text { 社会開発基金 }\end{array}$ & $97.10 \sim 99.01$ \\
\hline ジョルダン & $\begin{array}{l}\text { 人畜共通伝 } \\
\text { 染病 }\end{array}$ & $\begin{array}{l}\text { ジョルダン技 } \\
\text { 術科学大学 }\end{array}$ & $98.04 \sim 00.04$ \\
\hline $\begin{array}{l}\text { ドミニカ共 } \\
\text { 和国 }\end{array}$ & $\begin{array}{l}\text { 家畜用ワク } \\
\text { チン }\end{array}$ & $\begin{array}{l}\text { 中央獣医学研 } \\
\text { 究所 }\end{array}$ & $98.10 \sim 99.06$ \\
\hline マレーシア & $\begin{array}{l}\text { ウイルス学. } \\
\text { 分子生物学 }\end{array}$ & $\begin{array}{l}\text { アセアン家禽病研 } \\
\text { 究訓練センター }\end{array}$ & $99.04 \sim 02.04$ \\
\hline ウルグアイ & $\begin{array}{l}\text { エキノコッ } \\
\text { クス症 }\end{array}$ & $\begin{array}{l}\text { ウルグァイ共 } \\
\text { 和国大学 }\end{array}$ & $99.10 \sim$ \\
\hline ホンデュラス & 獣 医 学 & $\begin{array}{l}\text { 農牧省動物検 } \\
\text { 疫所 }\end{array}$ & $01.04 \sim$ \\
\hline パナマ & 飼料科学 & $\begin{array}{l}\text { 農牧研究所 } \\
\text { (IDIAP) }\end{array}$ & $01.04 \sim$ \\
\hline $\begin{array}{l}\text { ドミニカ共 } \\
\text { 和国 }\end{array}$ & 獣 医 学 & $\begin{array}{l}\text { サレシアノ農 } \\
\text { 業技術高校 }\end{array}$ & $02.04 \sim$ \\
\hline
\end{tabular}

平成 14 年5月現在，JICA資料による。派遣期間が空欄の ものは派遣中を示す.

事業は，幅広い技術や豊な職業経験をもつ 40 歳から 69 歳までの人材を募り, 途上国からの要請に応じて派遣す るというもので，青年海外協力隊のシニア版ともいえる 性格をもっている，国内的にも，「これまでに培った技 術，経験を開発途上国で生かしたい」という技術支援活 動に関心をもつ中高年層の人々は少なくなく，第二の人 生のありようとしても注目されるようになった。

事業が発足した 1991 年度では 3 力国に 11 名が派遣さ
（3）最近の畜産分野の派遣要請（平成14年春期募集分）

\begin{tabular}{|c|c|c|}
\hline 要 請 国 & おもなる指導項目 & 人員 \\
\hline イ & $\begin{array}{l}\text { 組織培養（豚コレラワクチン）・ } \\
\text { 畜産科学・分子遺伝学 }\end{array}$ & 3 名 \\
\hline $\begin{array}{l}\text { インドネ } \\
\text { シ }\end{array}$ & 牛乳処理・牛乳衛生管理 & 2 名 \\
\hline $\begin{array}{l}\text { パプア・ニ } \\
\text { エーギニア }\end{array}$ & 家畜飼料 & 1 名 \\
\hline シリア & 生物統計・酪農（乳牛の飼養管理） & 2 名 \\
\hline パナマ & 獣医学教育‧畜産（牛肉質改良） & 2 名 \\
\hline $\begin{array}{l}\text { ドミニカ } \\
\text { 共 和 国 }\end{array}$ & 獣医学教育 & 1 名 \\
\hline ボリヴィア & 酪農・家畜ウイルス疾病・牧野調査 & 3 名 \\
\hline
\end{tabular}

注：国際協力事業団, 青年海外協力隊事務局提供の関係 資料から抜粋

れているが，表2-（1）にみるように派遣国と派遣人数 は着実に増加し，2001 年度には34 力国に500名の派遣 を計画するまでに発展した。畜産分野でも，表2-(2) にみるように 6 力国に 8 名が派遣されている。 また平成 14 年春の募集（毎年，春と秋の 2 回，定期的に募集され る）では 7 カ国から 14 名の要請が寄せられているが (表2-(3)), 大部分は充足にいたっていない.

開発途上国の多くは，日本の戦後復興を高く評価し， そのノウハウを学びたいという意識をもっている，畜産 分野も例外ではなく, 日本の音産振興のいろいろな場面 で活躍した技術者，専門家に対する期待は大きく，こう した分野でのシニア海外ボランティアの派遣要請が増加 している.

発足後まだ日の浅い本事業は，国の内外できわめて好 評のうちに成長し，今後の技術協力の有力な制度として 発展してゅくものと考元られる。いろいろな分野で活躍 している日本の獣医師各位にとっても, 第二の人生の設 計プランのひとつとして準備して扔かれることを期待し たい.

(元・国際協力事業団国際協力専門員)

\section{意 外 な 関 係}

ペットで免疫力アップ?

ペットを飼う家庭の子供は病気への抵抗力が強い らしいことが, 英国の学者の調査で明らかになっ た.

15 日付の英紙インデペンデント（電子版）によ ると，英ウォリック大のマクニコラス博士が 138 人 の児童を対象に，免疫力の指標とされる，だ液中の

\section{新聞パトロール}

抗体を調べた，その結果，日ごろペットに触れてい る児童の方が免疫力が強いらしいことが分かった. 清潔すぎる環境で育った子供は免疫力が弱まる，と いう説を裏付ける結果かもしれないという。ただ し, 同博士は「ペットとべたべたし過ぎると健康上 の問題を起こす恐机もある」と警告している.

（ロンドン支局）

（読売新聞 2002 年 6 月 15 日 夕刊） 